\title{
Australian Airlines Industry Globalization and Labour Relations: A Case Study of Pilot Experience
}

\author{
Hani Abdulhafedh Thabit Yahya, Eman Salim Abdalla Rashid Saho \\ PhD of Philosophy in Management - Limkokwing University of Creative Technology-Malaysia
}

\section{Introduction}

This paper will discuss the case study about the Australian airlines industry globalization and labor relations and talks about the pilot experience by defining the issues and disagreement faced by the pilots, then, generating alternative solutions to these issues and selecting the perfect alternative among those and why its chosen for this application.

\section{DEFINITION OF ISSUES}

The domestic Pilots of Australian Federation of Airline went on an industrial dispute in 1989 for a twenty nine percent increase on their pay (Norrington, 1990). The result of the disagreement was a failure on the pilots and their union leading to gross resignation of pilots after the reestablishment of domestic airlines by the Federal Government.

Recent studies have appraised the 1989 disagreement and its consequences for pilot labour relations. Nevertheless, some studies have considered how changes from the inception of the dispute have influenced the important employment relationship. For many years, globalization comes to be known as one of the major factor required by the governments and firms in order to gain the competitive advantage position. The objective of this paper is to generate alternatives and the subsequent selection of the preferred alternative as a connection between globalization, and the dynamic role of the state and airline management in pilot labour relations. In search for alternatives and preferred alternatives we consider the following points: 1.) to what degree has globalization changed the position of the state and airline management in the pilot labour relations process 2.) How did airline management reacted to the alterations caused by globalization, and what plans were introduced since the inception of the dispute in 1989 3.) Has the position of the pilot unions changed, and what is their response to the alternative form of labour-management relations that has come up since the 1989 disagreement 4.) What are the preferred alternative forms of changes on domestic pilots' labour relations experienced since the 1989 disagreement, and what is their response to these alterations.

\section{Generating Alternatives}

\section{Deregulation and globalization of airlines industry and labour market}

Globalization has made an overwhelming impact on Australian domestic airlines since the 1989 pilots' disagreement. For many years, the airline industry and the labour market were deregulated, and management has assumed a more strategic move towards the employment relationship. Globalization can be defined as; a) the reduction in the obstacles oftrade and globalization of markets; b) the globalization of supply whereby no esteem is paid to national borders; and c) the restructuring of political and labour laws in order to maximize exports, cut down state social spending and end state economic regulation (Giles, 1996).

\section{Airlines industry deregulation}

To heightened international competitive advantage position and respond to globalization, the Australian Government had deregulated the airline industry and the labour market. Prior to 1990, the Australian airline industry was depicted by two airline agreement that aspired to prevent monopolies and encourage growth between privately owned Ansett and publicly possessed TAA/Australian Airlines (Bray, 1996). Legislative division between international and domestic transporters further guaranteed that the industry was intimately controlled by government until its deregulation in 1990 (Bray, 1997). Nonetheless, the progression of deregulation began in the 1970s when parallel flight and fare restrictions were discarded and regulations in respect of discount fares began to be eased (Quiggin, 1997).

\section{Labor market deregulation}

In the 1980s and 1990s Australia's industrial relations system experienced substantial transformations powered largely by the widely held neoliberal philosophy. Down to 1988, the Structural Efficiency Principle was presented into the existing Agreementto make sure that wage increases related to market efficiency, and in 
1993 the Industrial Relations Reform Act began the approach towards decentralization by reducing the responsibility of the Australian Industrial Relations Commission in dispute resolution (Deery, Plowman, Walsh and Brown, 2001). After the election of 1996, the Howard Government trailed completelabour market deregulation in the form of the Workplace Relations Act, which radically altered the course of Australian labour law (Pyman, 2001).

The Workplace Relations Act gave employers and employees the chance to bargain directly, without union participation, and permitted employees the freedom of association, thus eliminating closed shops. Novel techniques of enterprise bargaining were pioneered in the form of personal contracts, or Australian Workplace Agreements, and proficient agreements, which further diminish the need for unions (Deery et al., 2001).Even though one may claim that the Australian Government endeavored to implement an IPE approach viathe Workplace Relations Act, trade unions remain an imperative featureof Australian Industrial Relation and a substantialnumber of union practiced employment contracts (Lansbury and Wailes, 2004). This signifies that either the progression flopped, or the Federal Government has comprehended Australia's established collective system and dared not force the boundaries of their agenda too farGiles'(2000) methodology of rethinking and redesign national institutions and actorscorrespondingto that taken by the Howard Government in 1996.

\section{Management of the airline}

Universal competition due to globalization in the airline industry has put tremendous pressure on operating costs. In line with the International Transport Workers' Federation (1992), specifically enormous pressure on labour costs has resulted in inferior working conditions and amplified workloads. This is because labour makes up thirtypercent of an airline's costs, and contrasting to fuel and landing charges; labour is under the influence of direct management control. Furthermore, Qantas has put into operation the CM strategies including the layoff of 1000 employees, the usage of annual leave to trim down staffing, an embargo on the hiring of new staff and the conversion of three hundred full-time jobs to part-time status (Easdown and O'Brien, 2003). The airline point out that these actions are as a result of the response to the pressures of September 11, SARS and the global economic meltdown (Qantas, 2003), which buttresses Gialloreto's (1988) hypothesis that during economic recessions, airlines will make use of short-term, tactical plans to minimize costs. Added to the above, Qantas's rearrangements confirm the notion held by the ITF (1992) that globalization has altered management attitudes towards employees, and Human Resource Management's single handed approach has made workers more superfluous and interchangeable than ever before. Nesbit (1998) specifies, on the other hand, that redundancies and cut-backs are a concerning characteristic of Human Resource Management policies for Australian firms because they minimize employees' organizational commitment and trust in management.

\section{Selecting the Preferred Alternatives}

\section{Responses of airline management}

The analysis of Management of human resource from Ansett and Management of human resource from Qantas responses are divided into three parts. First, initial alterations fromthe dispute are scrutinized, seconded by management's ideas and reactions to industry and labour market deregulation, and union actions. Lastly, their notions on the challenges and consequences posed by globalization are scrutinized.

\section{Alterations since the dispute}

Due to the dispute, Ansett implemented pilots' wage increases, reputation and conditions of employment in line with the other workforce. Pilot management roles were moved from the airport to corporate headquarters and their employment agreements were made easy, which smooth the progress of uniform pay increases and minimized the need for disagreement resolution in the AIRC. These alterations were part of a large culture alteration program called the communications campaign (Bray, 1996), which concentrated on efficiency and profitability. In fact, Management of human resource from Ansett believes that in many ways, airline management forestalled the Workplace Relations Act by moving the focus of disagreement resolution for pilots away from the AIRC, six years before the Workplace Relations Act was introduced. Australian and Ansett established domestic unions after the disagreement and failed to negotiate with the AFAP. According to Management of human resource from Ansett, domestic unions increase efficiency because you maintained your own people. Further efficiencies were achieved through the elimination of seniority-based promotions and the implementation of productivity based pay. Pilot recruitment became more concerned on individuality and overall fit with the airline, which helped to stop future industrial dispute, and efficiency based pay benefited many pilots because they were able maximize their earnings if they worked more. Moreover, scope clauses, which need an airline to assign first rights to flying in subsidiary airlines to the parent airline's own pilots, were also eliminated after the disagreement. These management alterations, amount to reorganizing the pilot labour relations and a focus on effectiveness in the face of deregulation and globalization. The alterations started after the disagreement reproduces the strategic, effectiveness based approach of Human Resource Management. 
Specifically, the initiatives recognized by Management of human resource from Ansett and Management of human resource from Qantas can be sum up in terms of hard and soft Human Resource Management. Hard Human Resource Management sees employees as factors of production, systems and policies around business objectives. In comparison soft Human Resource Management viewsemployees as valued assets and trusted and whose dedication $t$ must be enhanced to achieve business objectives (Legge, 1995).

\section{Responses to deregulation and unions}

Management of human resource from Ansett admitted that the Workplace Relations Act allowed airlines to water down the power of unions so that they could put the interests of the firm first in a more adverse environment. He highlighted that Ansett always identify and respected the function of unions, however preserved the right to bargain with employees directly. On the other hand, Management of human resource from Qantas clarified that unions have not lost influence but have accepted a more consultative approach in response to the requirements of members because the nature of competition is such that people recognize that their future, promotional opportunities, job security and increases in salary are determined by the organization's profitability.

\section{Challenges and implications for the future}

Management of human resource from Ansett thinks that globalization, via the use of foreign pilot labour, enhanced the reorganization of airlines after the disagreement. Pilots recognized thatthere is a neglected workforce sitting offshore that is enthusiastic to come to Australia and be tapped. Both Management of human resource from Ansett and Management of human resource from Qantas stressedthat, considering globalization, Australia is still lagging behind other international airlines like Malaysian or Singapore, who use foreign agreement pilots to top up their own workforce. Management of human resource from Qantas thank that globalization has force the cost base of the airline. He saw air travel as a product and a price based purchasing decision, and the fact that transporters like Virgin Bluecan offer pilot handsome salaries.

\section{Union responses:}

\section{The Post-Dispute Experience}

The AFAP had been reluctant to arbitration. However, after the disagreement domestic airlines would only negotiate with their in-house unions, so arbitration became the only means the AFAP could use to provoke alteration.

\section{Initiatives of the New Union}

After the disagreement, the AFAP pursued a reorganization strategy. Distinct enterprise unions were introduced within the AFAP to symbolize the local pilots who were still members.

\section{Implications and Challenges}

The most vital issue caused by globalization is the proposed single aviation market between Australia and New Zealand.

\section{Responses of the pilot}

First, the skills of P1 and P2 at Qantas are scrutinized, followed by P3 from Virgin Blue and lastly P4 from Jet star. This move is used to assess differing manners towards management and to introduce an overview of pilot manners regarding the reform in airlines industry.

\section{Experiences with the AIPA.}

Neither pilot thinks that the AIPA plays a lawful function in the labour relations progression because the union has always focused on global pilots. National pilots were absorbed into the AIPA when Qantas amalgamated with Australian Airlines, and since then intercontinental pilots have always been favored. Another characteristic of the union that aggravates pilots is the intimate relations it holds with Qantas management. Both P1and P2 put in plain words that union officials often transfer to Qantas management, which they feel weakens the union's independence

\section{Challenges and Implications of Qantas}

Accepting that their overall position has significantly depreciated since the disagreement, both pilots felt that more sufficient union representation is required. They stress about long hours, inadequate rostering and an inability to make decisionwhen they can take leave as factors causal to fatigue and stress, which in turn endanger safety.

\section{Experiences with Management}

Distinguished job securityhascollapsed spectacularly since the dispute. The job for life approachthat once existed has been obliterated. P3 started with Virgin Blue some years ago, and since then he has seen a more mutualapproach materialize with the management frequently updating the pilot body on the company's performance. Relating employee relations as pretty friendly, there is nothing about Virgin Blue's methodology that obstructs his ability to institute reasonable terms of employment. He had seen numerous negative experiences whilst working in general aviation and for smaller transporters. The Human Resource initiatives 
used by his previous employer, made it difficult to negotiate reasonable terms of employment. AWAs were instituted and the pilot managers who had earlier negotiated contracts were substituted with Human Resource managers who had littleacquaintance of the piloting profession.

\section{Experiences with the AFAP}

AFAP did an excellent job of improvinghis terms of employment at Virgin Blue. The AFAP has developed over the years from a bankrupt position, to presently exercising substantial input into the Virgin

\section{Enterprise agreement}

The AFAP now deal with eighty percent of Virgin Blue pilots, and is also makingadvancement with Pacific Blue contracts. P3 sees the future of the union as a good one.

\section{Challenges and Implications}

The proposed Australia and New Zealand joint airspace agreement is the most vital issue facing pilots and their unions.P3 also disapproved of the recent airspace management alterations in Australia. These alterationsintroduced new class of airspace, via which commercial jets must come down, and the expectation was to seek for other smaller aircraft.

\section{Conclusion}

The 1989 pilots' disagreement enduringly redesigned labour relations in the airline industry and changed the balance of power between pilot unions and airline management. The case studies have established that the Australian Government has countered to the pressure for a competitive advantage position by deregulating the labour market and the airline industry. Alternatively, management has counteredby acceptingan increasingly individualistic approach towards the employment relationship, especially through strategic Human Resource Management in both forms. Thesealterations have impacted on pilots and pilot unions substantially. The end result of these alterations is a severe decline in pilot's conditions of employment. The once influential pilot body has been systematically concealed by the Federal Government and airline management. As a result, low-cost transporters can offer pilot wages just about half those of Qantas for exactly the same job. Qantas has reacted by instituting its own low-cost transporter, Jetstar, and by engaging in the cost cutting plans within the firm. Hence, Qantas pilots have lost faith in management and are acknowledging stress and fatigue due to workamplification. Globalization has forced management to minimize costs. Conversely, management must also acknowledge that ruthless cost cutting has an unpleasant impact on pilots, and minimizes the safety of their passengers. The results of this study signify that unions need to work towards communally beneficial outcomes with management, whilst keeping a certain degree of independence.

\section{References}

[1]. Bray, M. (1996) The Limits of Enterprise Autonomy: Enterprise Bargaining in the Australian.

[2]. Bray, M. (1997) 'Changing Patterns of Employment Relations' Melbourne: Oxford University Press.

[3]. Bray, M. (1997) 'The Domestic Airline Industry', in Lansbury, R. and Kitay, J. (ed.) Changing Patterns of Employment Relations, Melbourne: Oxford University Press.

[4]. Deery, S., Plowman, D., Walsh, J. and Brown, M. (2001) Industrial Relations: A Contemporary Analysis.

[5]. Gialloreto, L. (1988) Strategic Airline Management: The Global War Begins, London: Pitman.

[6]. Giles, A. (1996) "Globalization and Industrial Relations", Giles, A.; Smith, A.; Trudeau, G.

[7]. Giles, A. (2000) 'Globalization and Industrial Relations Theory', The Journal of Industrial Relations, vol. 42, no. 2, pp. $173-194$.

[8]. ITF (1992) 'The Globalization of the Civil Aviation Industry and its Impact on Aviation Workers', International Transport Workers' Federation, London.

[9]. Lansbury, R. and and Wailes, N. (2004) Employment Relations in Australia, Sydney: Allen \& Unwin.

[10]. M. Murray, T.M.G.P.a.M.Z. (n.d) Globalization and Regionalism: Employment Relations Issues in the Asia Pacific, Wollongong: University of Wollongong.

[11]. McGraw-Hill, I., Easdown, S., G. and O'Brien, S. (2003) 'Job Axe Falls at Qanta', The Herald Sun, April, p. 12.

[12]. Nesbit, P. (1998) Human Resource Rhetoric and Organizational Change.

[13]. Norrington, B. ( 1990) Sky Pirates: The Pilots' Strike that Grounded Australia, Sydney: ABC Books.

[14]. Pyman, A. (2001) 'Workplace Relations and Other Legislation Amendment Act 1996 (Cwlth) Experiences of Five Australian Trade Unions', The Journal of Industrial Relations, vol. 43, no. 3, pp. 340-347.

[15]. Qantas (2003) Qantas to reduce staff, Sydney.: Press Release.

[16]. Quiggin, J. (1997) 'Evaluating Airline Deregulation in Australia', The Australian Economic Review, vol. 30, no. 1, pp. 45-46.

[17]. The Domestic Airline Industry (n.d) 'Economic and Labour Relations Review', vol. 7, no. 1, pp. 132-164.

[18]. 'The Globalization of the Economy and the Worke', Selected Papers from the Annual CIRA, Quebec 